\title{
Paleotsunami evidence in the Bahía Inglesa coast (Atacama, Chile) based on a multi-approach analysis
}

\author{
R. Carballeira' ${ }^{1}$ - J. L. Peña-Monne ${ }^{2} \cdot$ X. L. Otero ${ }^{3,4} \cdot$ M. M. Sampietro-Vattuone ${ }^{5} \cdot$ C. P. Castro-Correa ${ }^{6}$. \\ M. V. Soto-Bauerle ${ }^{6} \cdot$ A. Pérez-Alberti ${ }^{3}$
}

Received: 20 September 2021 / Accepted: 27 January 2022

(c) The Author(s) 2022

\begin{abstract}
The Atacama coast is located in an area with a current high risk of tsunami, and the sedimentary deposits found in the Bahía Inglesa area, in the Morro sector, clearly indicate that this was also the case in the past. This investigation analyzes a paleotsunami sedimentary deposit consisting of a block field associated with three sand lobes oriented towards land on top of a marine terrace at an altitude of 70-75 m, which originated from a tsunamigenic event occurred between interglacial periods MIS 7 (ca. $210 \pm 10 \mathrm{ky}$ ) and MIS5e (ca. $125 \pm 5 \mathrm{ky}$ ). The deposits have been studied using a multiple approach combining geomorphological, sedimentological, biological, and geochemical criteria. The first type of criteria clearly indicate that the energy required to move the blocks and form the sand lobes could only have been generated by a tsunami. Sedimentological criteria constitute direct evidences of a marine origin due to the presence of siliceous remains from diatom species and spicules from strictly marine sponges, while geochemical criteria, such as the stable isotope signature and chemical composition, constitute evidence of a marine intrusion.
\end{abstract}

Keywords Atacama desert coast · Tsunami · Cliff-top boulder deposit · Marine terraces · Geomorphology · Geochemical signature $\cdot$ Diatoms

\section{Introduction}

The coasts of Chile are subject to a high incidence of tsunami due to high seismic activity associated to the Peru-Chile Trench, where the Nazca Plate subducts

This article is part of a Topical Collection in Environmental Earth Sciences on Earth Surface Processes and Environment in a Changing World: Sustainability, Climate Change and Society, guest edited by Alberto Gomes, Horácio García, Alejandro Gomez, Helder I. Chaminé.

R. Carballeira

r.carballeira@udc.es; rafael.carballeira@gmail.com

1 Centro de Investigacións Científicas Avanzadas (CICA), Facultade de Ciencias, Universidade da Coruña, 15071 A Coruña, Galicia, Spain

2 Departamento. de Geografía y Ordenación del territorio, Universidad de Zaragoza and IUCA, Pedro Cerbuna, 12, 50009 Zaragoza, Spain

3 Departamento de Edafoloxía e Química Agrícola, Campus Vida, Facultade de Bioloxía, CRETUS Institute, Universidade de Santiago de Compostela, 15782 Santiago de Compostela, Spain beneath the South American Plate (Kulikov et al. 2005). The magnitude of the energy released in the interaction interplates generates a high frequency of earthquakes capable of triggering tsunamis, many of which have impacted these coasts in the last four centuries, with run-up in the order of 15-21 $\mathrm{m}$ along the area adjacent to the coastline (Barrientos et al. 2007; Ruiz and Madariaga 2018). Southcentral Chile is the most extensively studied area, because this coastal region is the most tectonically active where

4 REBUSC, Red de Estaciones Biológicas de La Universidad de Santiago de Compostela, Estación de Biología Marina A Graña, Casa Do Hórreo, Rúa da Ribeira, No 1-4, A Graña, 15590 Ferrol, Spain

5 Laboratorio de Geoarqueología, Universidad Nacional de Tucumán y CONICET, Miguel Lillo, 2054000 San Miguel de Tucumán, Argentina

6 Departamento de Geografía, Facultad de Arquitectura y Urbanismo, Universidad de Chile. Portugal, 84, Santiago de Chile, Chile 


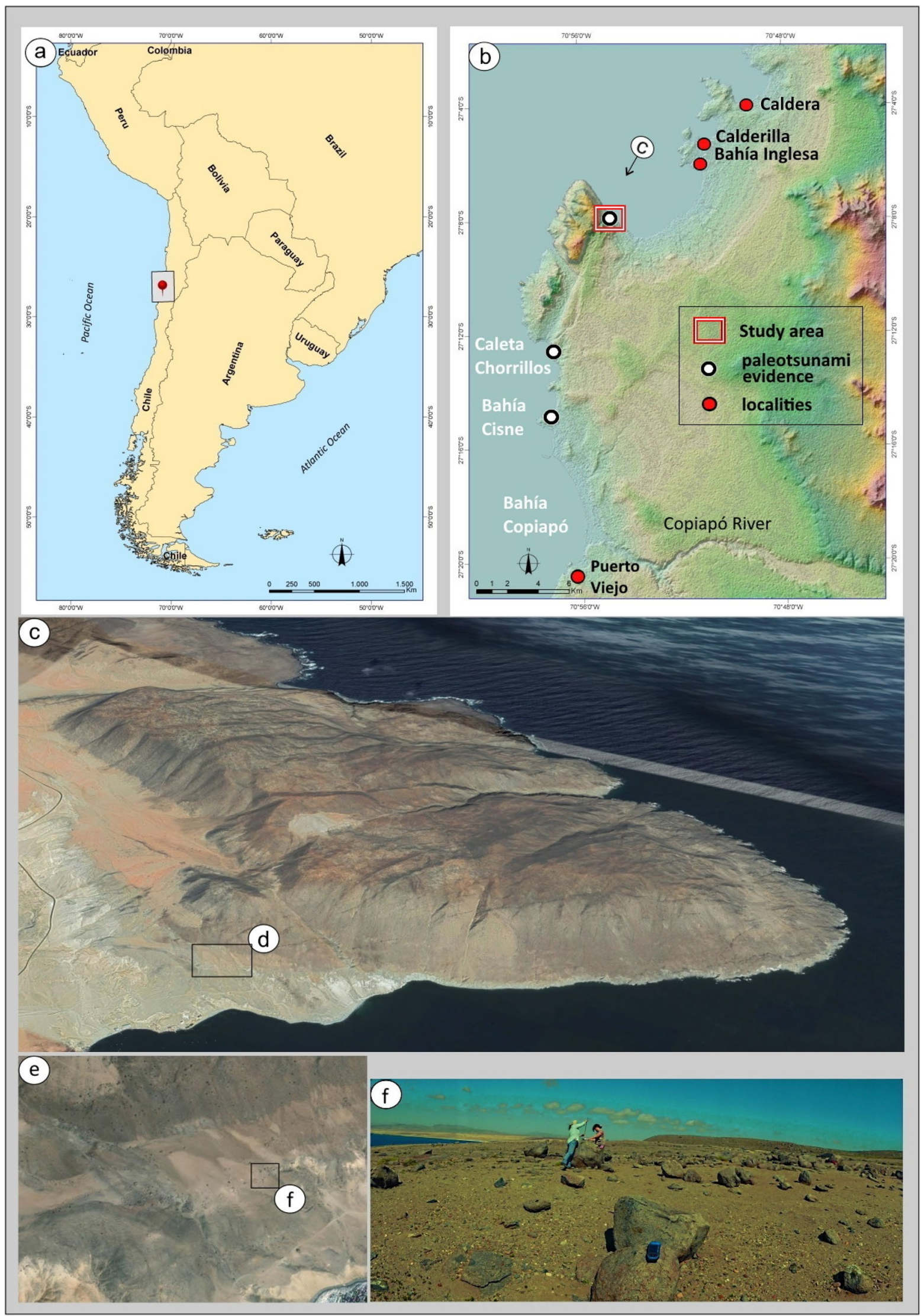


4 Fig. 1 a Location of the study area indicate by a rectangle of the coast of Bahía Inglesa in the Atacama region (Chile); b Topography of the studied sector; $\mathbf{c}$ General view and situation of the Morro Norte area and location of the study area; d Paleotsunami deposit of sandy lobes and boulder fields (DigitalGlobe (C) 2016); e Boulder field situation; and $\mathbf{f}$ Panoramic view of the boulder field

large megathrust earthquakes frequently occur. However, the historic tsunamogenic events in the North coast is not well known yet (León et al. 2019; Costa and Andrade 2020), although the identification of these events has fundamental implications for current understanding of the risk and potential magnitude of earthquakes in northern Chile.

Regarding Atacama region, historical reports of tsunamis are available. Thus, on April 11, 1819, there was a magnitude 8.5 earthquake at sea off Caldera. This earthquake lasted approximately $7 \mathrm{~min}$ and almost completely destroyed the city of Copiapó. In Caldera, a tsunami with waves up to four meters high was registered. The tsunami reached all coasts within a radius of $800 \mathrm{~km}$, reaching the coast of Hawaii. More recently, on November 11, 1922, the Vallenar earthquake, also in Caldera with its epicenter located in the Andes mountains range, hit the Chilean coast about 15 min reaching the waves a maximum height of $8 \mathrm{~m}$ and destroying several civil buildings. In Chañaral (1922), the tsunami consisted of three waves which destroyed most of the buildings and road infrastructure (http://www.sismo24.cl/500sismos/730h1922va 11.html, http://www.sismologia.cl/links/terremotos/). Three waves were also observed in Coquimbo, the last one being the most destructive, with a maximum height of seven meters. In Huasco, the wave was five meters high. Other towns such as Carrizal Bajo, Tongoy, and Los Vilos also suffered the impact of the sea.

Recently, Klein et al. (2017) analyzed the coupling between the two plates from $27^{\circ} \mathrm{S}$ to $37.5^{\circ} \mathrm{S}$ after the 2015 Illapel earthquake and concluded that there are two possible future seismic scenarios compatible with each other. These authors raise the possibility that an earthquake of magnitude $\geq 9$, belonging to the 300 -year supercycle, may occur in a rupture zone that spans from Concepción $\left(37^{\circ} \mathrm{S}\right)$ to at least La Serena $\left(30^{\circ} \mathrm{S}\right)$ or even further north. On the other hand, there is a high probability that, after the Illapel earthquake, there will be a northward propagation of seismicity, causing a rupture of the segment in Atacama that would generate an earthquake of magnitude $\geq 8$. According to these authors, the coupling in this segment is mature enough to generate an event of this magnitude; therefore, this scenario seems the most likely of the two. In any event, the tsunami generated after either one of the two proposed seismic events and would affect the coasts of the Atacama Region with a very significant magnitude. For this reason, the probability of a high-energy marine event in the area is very high.
In this context, the study of the frequency and intensity of tsunamis can contribute to the prediction of new catastrophic events. While the historical record of earthquakes and tsunamis in the last two centuries has been reasonably well determined (Fritz et al. 2011; Donnelly et al. 2017; Ruiz and Madariaga 2018), however, the lack of information for prehistoric periods is especially relevant in the Atacama Desert region, where the geological record of tsunamis has been assumed to be scarcer due to the unfavorable conditions for preservation, with a steep coastal geomorphology and high levels of erosion in the hyper-arid climate (Spiske et al. 2013). However, recently, in the Atacama region, towards the North of Copiapó River estuary, was discovery many boulder fields associated with sand lobes in the opposite direction to the sea and that could be related to paleotsunamis. For this, a study has been carried out that integrates sedimentological, geochemical and biological analyzes, including characterization of the boulders, composition and properties of the substrate, isotopic ratios and diatoms analyzes.

\section{Materials and methods}

\section{Geomorphological and environmental setting}

The north coast of Chile has a straight general layout but locally abrupt with a succession of small beaches, pocket bays, a steep coastal slope dominate by coastal cliffs. The study area is located in Bahía Inglesa (Fig. 1), a small bay in the coastal Atacama Desert region. Two topographic and geological environments converge. In one side, the ancient massif of the Morro de Copiapó, located on the western sector (295-100 m a.s.1.). On the other side, the area of Bahía Inglesa, in the eastern sector, with altitudes between 100 and $0 \mathrm{~m}$ a.s.l. formed by Neogene and Quaternary deposits (Figs. 1, 2a). The Morro de Copiapó is composed by granodiorites, quartzite diorites, and tonalite of Jurassic age. Granodiorites Morro Copiapó, Godoy et al. (2003)). They are densely fractured conditioning the fluvial network and the morphology of the cliffs over the Pacific Ocean. These materials are bordered on their margins by faults, highlighting the Morro Copiapó fault that marks the contact with the Bahía Inglesa (Fig. 2a), although there are also small rocky outcrops close to Bahía Inglesa locality (Figs. 2a, b). The Bahía Inglesa Fm was sedimented during the Neogene discordantly covering the rocky substrate of the eastern sector of the Morro de Copiapó. This marine-littoral sedimentary environment is characterized by several such as conglomerates, breccias, mollusk lumaquelas, sandstones and grayishyellow shales; the last ones may have muddy appearance and intercalations of diatomites, phosphorites and grayish and whitish cinerites (Carreño 2012). Abundant fossils like 


$\begin{array}{lr}27^{\circ} 07^{\prime} 54.4^{\prime \prime S} & 27^{\circ} 07^{\prime} 54.4^{\prime \prime} \mathrm{S} \\ 70^{\circ} 55^{\prime} 25.23^{\prime \prime} \mathrm{W} & 70^{\circ} 54^{\prime} 12.7^{\prime \prime} \mathrm{W}\end{array}$

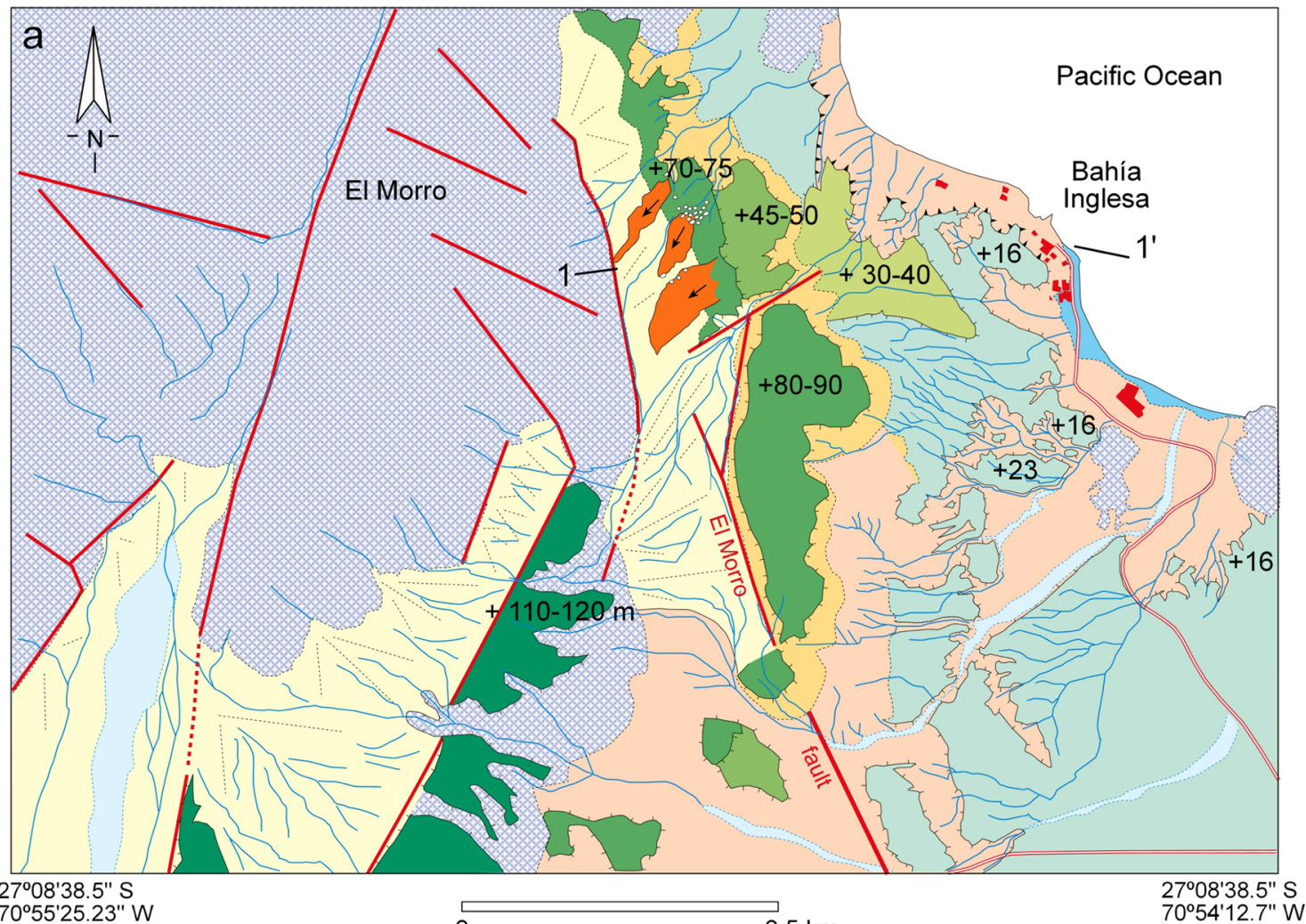

Geological features Litoral morphologies
and fluvio-marine terraces Palaeotsunami remains
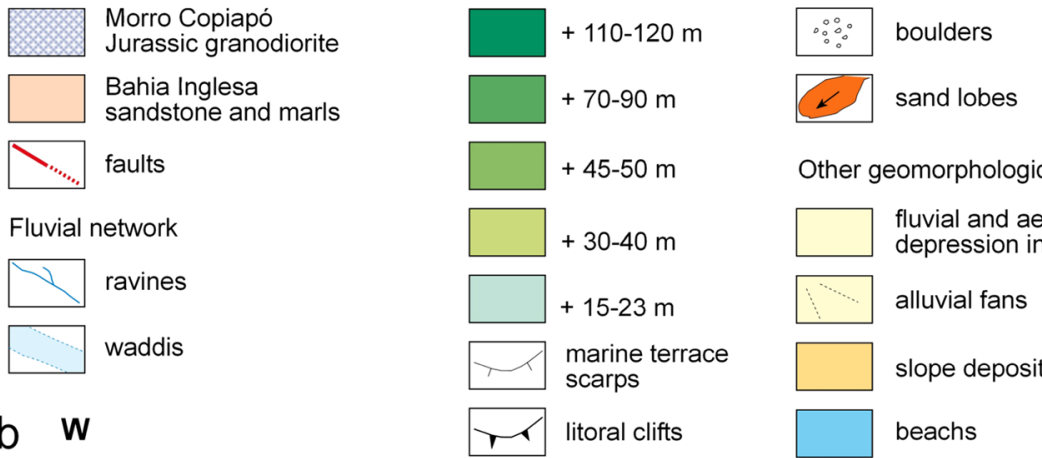

houses

Other geomorphological features

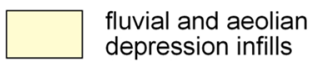
depression infills

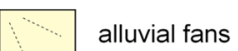

b w
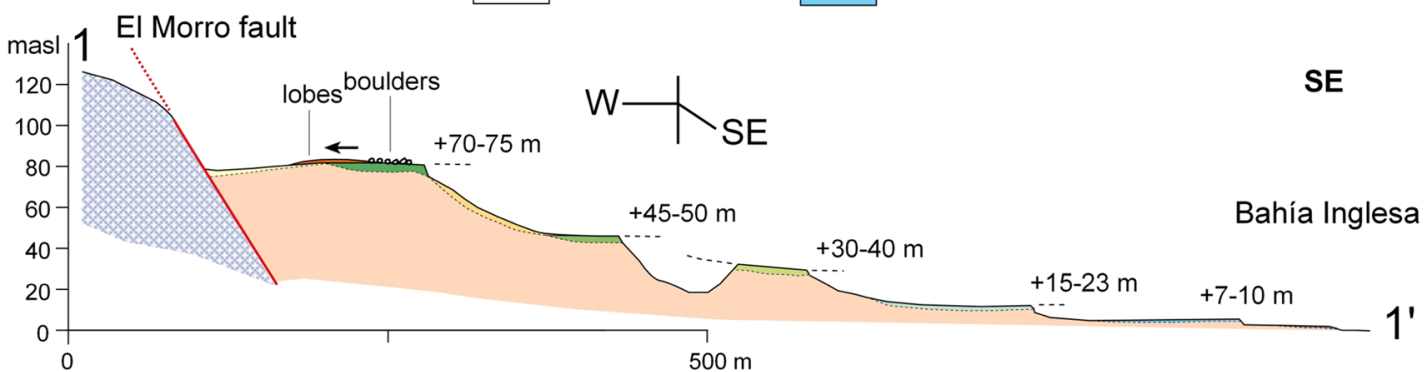

Fig. 2 a Geomorphological map of the study area (see Fig. 1e); b cross-section and location of the palaeotsunami remains

scales and fish, skeletal of birds, cetaceans and sea lions or many mollusk species have been found (Guzmán et al. 2003; Marchant et al. 2000). Achurra (2004) interpret this geological formation as the result of the continental platform sedimentation with transitions toward slope deposits during the Neogene. In addition, the north and central Chilean 
coast was subject to a continued subduction process among plates along the Cenozoic that determined the main tectonic deformations (Hartley et al. 2000; Marquardt et al. 2000a, 2000b; Laursen et al. 2002; González et al. 2003; Encinas et al. 2008).

The Bahía Inglesa Fm and part of the granodiorites of the Morro de Copiapó were discordantly covered by eight levels of Quaternary marine terraces named Estrato de Caldera Fm (Marquardt et al. 2000a, 2004). Above them, there are older stages, badly preserved, located over $300 \mathrm{~m}$ a.s.l. The ages of these morphologies are important to calculate the coastal uplift during the Quaternary. Up to now, the average rates are assessed on 0.3/0.4 m/ka (Goy et al. 1992; Macharé and Ortlieb 1992; Marquart et al. 2004).

Climatic conditions are those of Coastal Desert with abundant clouds (BWn) according to Köppen classification. The scarce rainfalls are concentrated in few days during the winter (June and July). The presence of coastal fogs, locally named camanchacas, is very frequents/relevant source of water? They are formed by the wet air traversing the Humboldt Current. However, the most significant phenomenon of interannual variability is the ENSO. In the area of Bahía Inglesa-Caldera rains are concentrated in June and July, normally in one to three annual events, annual average is about $26.9 \mathrm{~mm}$ (Caldera). There are sporadic extreme events, like in 1997, when the weather station of Caldera recorded $84.0 \mathrm{~mm}$ in August, and 90\% fell in 1 day (Cereceda et al. 2000). Average annual temperature is of $16.1^{\circ} \mathrm{C}$, with large daily oscillations.

The northwest-southeast orientated embayment of Bahía Inglesa is protected from the dominant south-west waves by a high rocky headland in the south extreme. The swell on the coasts of Chile is mainly characterized by waves generated in large ocean sectors, specifically from low-pressure systems in the South Pacific, and head towards the southern extreme of South America (Monárdez et al. 2008). The local mean tidal range is $\sim 1 \mathrm{~m}$ in the coast of the Atacama Desert region, with a regional estimate of the mean significant wave height of $2.04 \mathrm{~m}$ (Campos 2016), while it reaches $4 \mathrm{~m}$ in the extreme south of Chile according to satellite measurements (Fugro OCENOR: http://www.oceanor.no/Services/World waves/WW_database).

\section{Description and analysis of the boulder field}

The distribution pattern of unusually large boulders in the study area were mapped using a Stonex 8 GNSS GPS. The analyzed blocks were associated with a 150 -m-long sand lobe (Fig. 2) composed of very fine sands. Fifty-four blocks were characterized. For each block, its long axis $(L)$, intermediate axis $(I)$, and short axis $(S)$ were measured to determine its volume. Because the product of L.I.S is a simplification of the volume of the block (Robinson et al. 2008), triangulation was performed based on the methodology of Roig-Munar et al. (2015), whose average result reduces volumetric values by $15 \%$ and gives a more reliable estimate of the actual volume of the blocks. From this volume, granite density $\left(2.63 \mathrm{t} / \mathrm{m}^{3}\right)$ was used to calculate their mass.

To analyze the blocks, the values of the Transport Figure (TF; Eq. 1, Scheffers and Kelletat 2003), which uses basic block parameters (weight, altitude, and distance from the coast) were calculated. TF values is an estimates the energy necessary to mobilize and transport each block.

$\mathrm{TF}=P \cdot D \cdot H$

where $P$ is the weight of the block in tons, $D$ is the distance from the block to the sea in meters, and $H$ is the height of the block above sea level in meters.

In this case, given the location of all the blocks on the marine terrace $+70 / 75 \mathrm{~m}$ asl, the distance to the paleocoast found on the lower marine terrace, located at $+45 / 50 \mathrm{~m}$ asl, was considered. The same technique was followed to estimate parameter $\mathrm{H}$ adjusted to the paleocoast. The relationship between the boulders morphometry and their spatial arrangement variables has been explored using a Spearman correlation $\left(r_{\mathrm{s}}\right)$ analysis, applying a t Student test to determine the level of statistical significance of correlations between parameters. All statistical analyses were performed using XLSTAT (2020).

\section{Sediment analysis of sandy lobes}

Samples of $200 \mathrm{~g}$ of the greater sandy lobe in the Bahia Inglesa deposit have been collected in two points at four depths (i.e. 0-5, 5-10, 10-15 and 15-20 cm). The sized particles were separated using the Robinson pipette method (Gee and Bauder 1986). Twenty grams of dry sample were subjected to attack by hydrogen peroxide (15\%) for 5 days to remove organic matter; $50 \mathrm{ml} \mathrm{HCl}(1 \mathrm{M})$ were then added and left for $20 \mathrm{~min}$, occasionally shaking, to remove oxides and hydroxides of $\mathrm{Al}$ and Fe. The sample was then washed until free from chlorides, and sodium hexametaphosphate was added as a dispersing agent. Mechanical agitation ( $2 \mathrm{~h}$ ) used in combination with chemical treatments enhances dispersal. After dispersal, the samples were sieved in the following six fractions: Fine sand $\left(5 \times 10^{-2}-0.2 \mathrm{~mm}\right)$, medium sand $(0.2-0.6 \mathrm{~mm})$, coarse sand $(0.6-2 \mathrm{~mm})$ and gravels $(>2 \mathrm{~mm})$. Clay and silt fraction were determined in the fraction less than $510^{-2} \mathrm{~mm}$ according to the Robinson pipette method (Gee and Bauder 1986). Total organic carbon (TOC) was determined by an elemental analyzer (LECOCNS model 2000) after pretreatment of the samples with $6 \mathrm{~mol} \mathrm{l}^{-1} \mathrm{HCl}$ to eliminate the possible presence of inorganic carbon. $\mathrm{pH}$ was determined in an extract 1:2.5 (10 g of sediment and $25 \mathrm{ml}$ distilled water), electrical conductivity 
(EC) in an extract 1:5 (Dellavalle 1992). Soluble anions and cations were analyzed in an extract 1:5 previous filtration of the sample by $0.45 \mu \mathrm{m}$. Dissolved cations was measure by atomic absorption spectrometer with a Perkin Elmer 3100, while anions was measured by ion exchange chromatography with a Dionex ICS-5000 Capillary Ion Chromatography System (Dahnke and Whitney 1988). The mineralogical content was determined in ground samples of the sand lobes by fluorescence of X-ray spectrometry (XRF) with a Bruker-Nonius wavelength dispersing $\mathrm{S} 4$ fluorescence spectrometer in the University of A Coruña's Research Support Service (Servizo de Apoio a Investigación, S.A.I.).

\section{Stable isotopes analyses}

Samples of the sand lobes to four depths $(0-5,5-10,10-15$, $15-20 \mathrm{~cm}$ ) of the Bahía Inglesa deposit were ground powder. Also, three spatial replicates of soils samples $(0-5 \mathrm{~cm})$ were collected in the south of the study area, one sampling point are inland soils of the Atacama region (AT1-AT2) in the upper Copiapó river basin near the city of Copiapó (Copiapó, Chile), and other sampling point are soil samples in the coastal area (CO1-CO3) near and the mouth of the Copiapó river and the town of Puerto Viejo (Copiapó, Chile). The possible presence of carbonates in soil and sediment samples has previously been ruled out by direct acidification with $1 \mathrm{~N}$ $\mathrm{HCl} 1: 10(\mathrm{p} / \mathrm{v})$ at room temperature during $12 \mathrm{~h}$ according to Verardo (1990). Samples were then washed by centrifugation in deionized water. Finally, the samples were dried in an oven at $40{ }^{\circ} \mathrm{C}$ overnight and subsequently ground. The natural abundance of ${ }^{13} \mathrm{C}$ in sediments was determined after conversion of dried samples to $\mathrm{CO}_{2}$ in an elemental analyzer (Carlo Erba Instruments EA 1108) coupled through interface ConfloIII (ThermoFinnigan) to an isotope-ratio mass spectrometer (Thermo Finnigan MAT253). Natural abundance values of ${ }^{13} \mathrm{C}$ were expressed as isotope ratios (\%o) according to the formula:

$\mathrm{d} X=\left[\left(R_{\text {sample }} / R_{\text {standard }}\right)-1\right] 1000$,

where $X={ }^{13} \mathrm{C}, R={ }^{13} \mathrm{C} /{ }^{12} \mathrm{C}$, and standard $=$ Peedee Belemnite carbonate for $\delta^{13} \mathrm{C}$. All isotope determinations were run in duplicate.

\section{Diatoms and sponge spicules preparation samples}

$30 \mathrm{~g}$ sediment samples of the sand lobes to four depths $(0-5$, $5-10,10-15,15-20 \mathrm{~cm}$ ) of the Bahía Inglesa deposit were wet-sieved through nested $350-\mu \mathrm{m}$ and $5-\mu \mathrm{m}$ sieves to concentrate the diatom size fraction, as well as to remove silt and clay particles. The diatom and sponge spicule fractions were purified of mineral particles using a high-density $\mathrm{ZnBr}$ solution $\left(2.5 \mathrm{~g} \mathrm{~cm}^{-3}\right)$; the light fraction was then recovered and washed with distilled water, followed by successive centrifugations at $900 \times g$ for $4 \mathrm{~min}$. Diatom sample preparation followed the method described by Renberg (1990): aliquots were placed on clean coverslips and allowed to airdry for LM analysis. For the preparation of permanent slides, coverslips were mounted on glass slides using Naphrax ${ }^{\circledR}$ resin (refractive index $=1.74$; Brunel Microscopes: http:// www.brunelmicroscopes.co.uk/). Diatoms and sponge spicules were examined under LM with a Nikon Eclipse E600 equipped with a plan-apochromat $100 \times$ objective (N.A. 1.30) and differential interference contrast (Nomarski) optics. LM photographs were taken with an AxioCam ICc5 Zeiss digital camera. Concentrations of diatoms and sponge spicules were estimated by adding to a known volume of the samples a known concentration of polystyrene microspheres with $5 \mu \mathrm{m}$ diameter, using a calibrated stock solution with 1000 microspheres $\mathrm{cm}^{-3}$. Aliquots of samples were mounted on aluminum stubs, sputtered with platinum/ palladium $(15 \mathrm{~nm})$ for 1 min using a Cressington Sputter Coater 208HR SEM coating system, and studied with a Field Emission SEM JSM 7200F (JEOL) microscope operated at $15 \mathrm{kV}$ in the Research Support Service (Servizo de Apoio a Investigación, S.A.I.) of the University of A Coruña.

Diatom identification was based on standard diatom floras Krammer and Lange-Bertalot (2000-2006), Lange-Bertalot (2000), Hoffman et al. (2011) and Witkowski (2000), as well as region-specific references (Hustedt 1927; Frenguelli 1929, 1936; Rumrich et al. 2000; Servant-Vildary 1978; ServantVildary and Blanco 1984). The autoecological criteria used to define life forms and salinity (halobian) preference groups were mainly Vos and Wolf (1988, 1993), Hemphill-Haley (1993) and van Dam et al. (1994), also regional data of Servant-Vildary et al. (2002) and Hassan et al. (2009) were used as secondary references for inland water diatoms.

\section{Results and discussion}

\section{The geomorphological context}

The western limit of Bahía Inglesa is formed by the cliffs of granodiorite of the Morro de Copiapó and some reliefs of the Bahía Inglesa Fm partially covered by Quaternary marine terraces. The block of Morro de Copiapó is characterized by flattened surfaces bordered by abrupt scarps forming straight cliffs over the Pacific Ocean, while towards Bahía Inglesa, there are tectonic steps bordered by faults. These structures give place to the formation of two small elongated depressions NNE-SSW oriented (western basins) and to another depression NNW-SSE oriented following the El Morro inverse fault (Figs. 2a, b). The last one is one of the most active faults affecting very young Quaternary deposits (Castro Correa 2014). Due to its softer lithological 
Fig. 3 a Panoramic view of the study area landscape in Bahía Inglesa, sand lobes and field boulder deposits on the marine terrace $+70-75 \mathrm{~m}$ at the cliff top (see Fig. 1e and Fig. 2), b detail of the sand lobe deposits
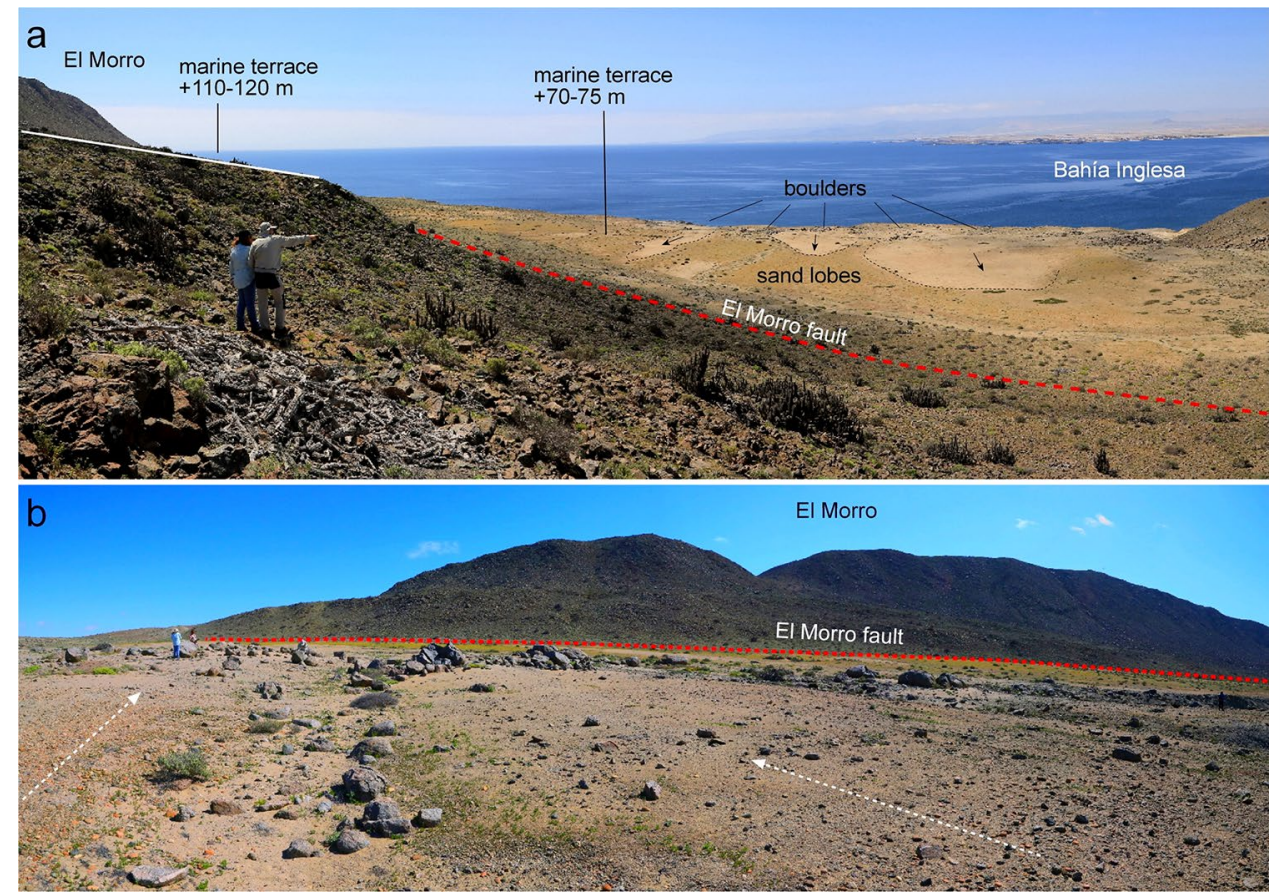

composition, the Bahía Inglesa Fm was severely eroded by the fluvial network with the formation of rills, deep ravines, wide waddis or badlands.

The most important geomorphological features are the Quaternary marine terraces stepped since the El Morro towards the coastline. These terraces reach between 0.9 and $3 \mathrm{~m}$ thickness of gravels, sands, and mollusk shells, sometimes forming compacted lumachelas. Normally, sand forms the matrix in the mollusk layers. These formations are known since one and a half century, but was Paskoff (1970) who started with the researchers in the area during the $60 \mathrm{~s}$ and $70 \mathrm{~s}$. Higher and older terraces are located further inland from Bahía Inglesa as pointed by Marquard et al. (2004) and Quezada et al. (2007) at 139, 205-210, and 300-320 m a.s.l. In the study area, the higher level is located at 110-120 m a.s.l. forming a flatten area affected by tilt and fluvial erosion (Figs. 2a, b). This terrace was formed during the MIS9 interglacial, and was dated around $330 \pm 10 \mathrm{Ky}$ (Marquardt et al. 2004). The level is extended along the graben side of the Chorrillos ravine, in the east side of El Morro. It forms a paleocliff, together with some hard layers of Neogene calcarenites of the Bahía Inglesa Fm. On its foot, there are younger marine terrace levels. These younger accumulations are at + 70-90 m, +45-50 m, +30-40 m, + 16-23 m, +7-10 m a.s.1., although the last one has smaller surface (Figs. 2a, b). There are several deformations due neotectonic activity, highlighting the faults uplifting the terrace of $+70-75 \mathrm{~m}$ to $+80-90 \mathrm{~m}$ (Fig. 2a). Marquardt et al. (2004), using the U/Th and ESR datings of Radtke (1987) and Leonard et al. (1994) in areas close to Bahía Inglesa and the correlation of warm water bivalves (Ortlieb et al. 1997) propose a chronological sequence of marine terraces. The $+70-90 \mathrm{~m}$ terrace would belong to MIS 7 (around $210 \pm 10 \mathrm{ky}$ ), the $+45-50 \mathrm{~m}$ terrace was fomed during the MIS5e $(125 \pm 5 \mathrm{ky})$, the $+30-40 \mathrm{~m}$ terrace during the MIS5c $(105 \pm 5 \mathrm{ky})$, the $+16-23 \mathrm{~m}$ terrace during the MIS5a $(83 \pm 3 \mathrm{ky})$, and the lowest was formed during the Holocene $(6 \pm 2 \mathrm{ky})$.

The surface of the marine terraces shows features characteristic from aeolian deflation, giving place to the development of a reg of rounded gravels due to the loss of the fine matrix. The pavement of gravels is widely extended; they have siliceous composition, well rounded and large flattening index. Some gravels have badly developed rock varnishes and aeolian polish, there are also many broken and superficially corroded specimens due to lichens and mosses biochemical action that use to locally form biological crusts (Castro Correa 2014). In the slopes between the steps of the marine terraces, the Bahía Blanca Fm appears, although there are also coverings composed by eroded gravels coming from the immediately upper terrace. In the case of the +110 and $+70 \mathrm{~m}$ terrace, giving its position next to the Morro, there are alluvial cones (Fig. 2a).

\section{Boulder field, morphometry and distribution of the boulders}

Over the marine terrace located $+70-75 \mathrm{~m}$ a.s.l., the satellite images (Fig. 1d,e) as well as the photographs taken from El Morro (Fig. 3a,b) show large boulder field at the top of the cliff accompanied by three large lobes of sandy sediments. These lobes show elongated shape NE-SW oriented over the 
terrace and the alluvial fans of the depression formed in the contact with the El Morro fault.

The morphometric values of the boulders are shown in Table S1 and Figure 1S. The average weight of the 54 boulders was $1.15 \mathrm{t}$; and their average distance from the coastline was $112.78 \mathrm{~m}$, with an average orientation of $129^{\circ}$ (Figure 1Sa). The shape of the boulders is mainly equant and elongate unfavorable to rolling transport (Figure 1Sb), in fact, the boulders did not show any signs of wave abrasion or friction marks. Conversely, they have been affected by post-depositional desquamation processes. Regarding shape, mean Corey Shape Factor (CSF) (Corey AT 1949) was found to be 0.57 , with a value of 1 representing a perfect sphere. Mean altitude of the boulder field was $68.79 \mathrm{~m}$ a.s.l. on the cliff-top of the marine terrace at $+70-75 \mathrm{~m}$ a.s.l., while at the base of the cliff there is a marine terrace $t+45-50 \mathrm{~m}$ a.s.l. (Fig. 2). The orientation of the boulders shows a significant correlation with the distance to the sea $\left(r_{\mathrm{s}}=-0.342 ; p\right.$ value $\left.<0.05\right)$, the most distant boulders to sea $(120-127.6 \mathrm{~m})$ are clearly oriented to the NE $\left(0-80^{\circ}\right)$, but the weight and the shape of the blocks does not show significant correlation with the distance to the sea. Therefore, the tsunami that originated this deposit in Bahía Inglesa occurred in the interval that both terraces were formed between two interglacial periods MIS 7 (ca. $210 \pm 10 \mathrm{ky}$ ) and MIS5e (ca.125 $\pm 5 \mathrm{ky}$ ) according to the chronological frame proposed by Marquart et al. (2004). The combination of the disposition of the deposit on the cliff-top in the hyper-arid environment of the Atacama coast, only affected by aeolian processes and the historically low human presence have preserved this paleotsunami deposit (Spiske et al. 2013; Ishimura and Miyauchi 2015).

The study of boulders transported either by tsunamis or by storms is of great value for reconstructing this type of events occurred in the past (Nott 2003), as well as for estimating the hydraulic properties that have given rise to these accumulations (Imamura et al. 2008). The distinction between them is based on a set of sedimentological, morphological, chronological, stratigraphic, and organizational criteria (Roig-Munar 2016). Goto et al. (2011) proposed that boulder measurements and their spatial distribution can be used to estimate the velocities of wave flows generated by storms or tsunamis. The interlocking boulder deposits aligned along the coasts, either forming a single strip or several overlapping strips, are clear indicators of tsunami-associated transport, according to Browne (2011), Weiss (2012), Scheffers and Kinis (2014), and Roig-Munar et al. (2017). In the last decade, the discussion on boulders transport with the aim of discerning between those originated by tsunamis and by storms has led to a more thorough consideration of the role of storms on rocky shores (Etienne and Paris 2010; Switzer and Burston 2010; Roig-Munar et al. 2017).

The formula applied by Scheffers and Kelletat (2003) simplifies the equations, thus allowing for an approximation to limits and conditions to obtain the storm column of a tsunami wave. According to Scheffers and Kelletat (2003), when applying the TF to their research, TF values up to 230 correspond to boulders transported by storm surges, while boulder with TF $>250$ correspond to those transported by tsunami waves. In this case, the criteria of Roig-Munar et al. (2015) for tsunami boulders in the Balearic Islands have been used. These authors established a threshold of $\mathrm{TF}>1000$ to consider a tsunami-related origin, which offers a greater certainty by establishing a higher margin than that considered by Scheffers and Kelletat (2003).

Applying the Transport Figure equation, an average TF value 2607.53 was obtained for the 54 boulders analyzed. Forty-five blocks had TF values $<1000$; these boulders showed average dimensions $\left(L^{*} I^{*} S\right)$ of 112,73 , and $48 \mathrm{~m}$ and an average weight of $1.12 \mathrm{t}$ (Fig. 3), and they were located at an average distance of $112.50 \mathrm{~m}$ from the coastline and at a mean altitude of $68.72 \mathrm{~m}$ above the current sea level, with an average orientation of $125.33^{\circ}$. The theoretical calculations using the Scheffers and Kelletat (2003) formulas determines that a tsunami wave can move boulder of $1 \mathrm{t}$ at a height of between 20 and $30 \mathrm{~m}$, so the boulder field is in this theorical range at an altitude of $23.79 \mathrm{~m}$ from the paleocoast line following the lower marine terrace at $+45-50 \mathrm{~m}$ a.s.l. (Fig. 2). This theoretical possibility of transport of large boulders by tsunami events has been verified in the Paleotsunami deposit of Bahía Cisne in nearby coastal areas (Fig. 1), with a boulder field on the shore at $+20 \mathrm{~m}$ from actual sea level (Abad et al. 2019). The rose diagram (Fig. 4) shows that the A-axis presents dominant SE-NW direction, parallel of the paleocoast, and NE-SW direction like the sand lobes orientated with the possible wave flood direction, with a predominant landward movement with a rapid loss of transport capacity of the wave flow inland from the cliff edge.

The boulder field at the top of the cliff in Bahía Inglesa is analogous to the boulder transport by tsunami events documented in other paleotsunami deposit on the near coast of Bahía Cisne (Abad et al. 2019), or on the shore in coastal areas of the Central Chile (Spiske and Bahlburg 2011; Bahlburg and Spiske 2012, 2015; Aedo et al. 2021) and the Peruvian coast (Spiske et al. 2013), but also the boulders field on the shore with a tsunamigenic origin are documented 


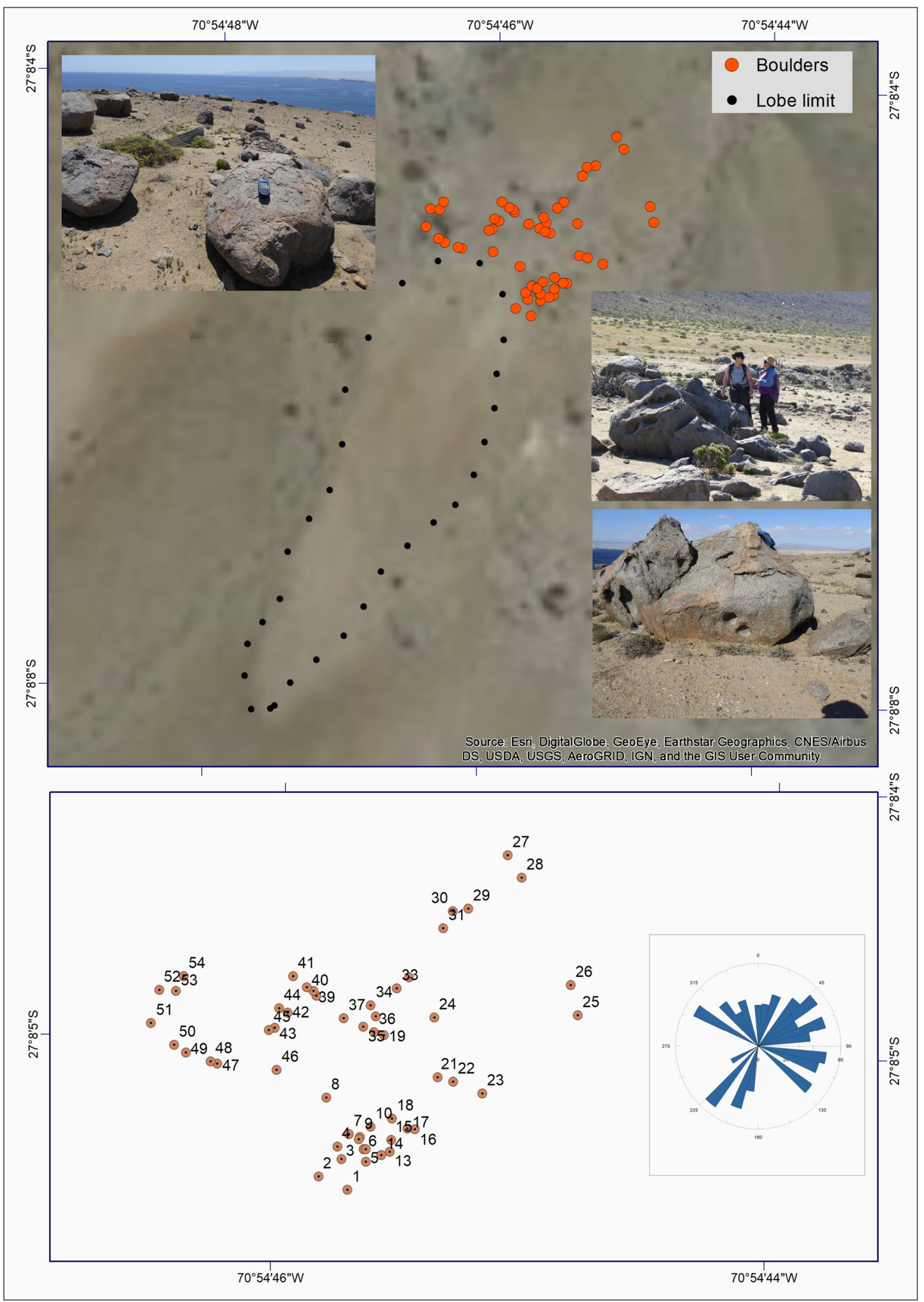

Fig. 4 Boulder distribution and representation of the A-axis direction binned every $10^{\circ}$, the points indicate each of the measured blocks 
on other Pacific coastal areas, such as the Solomon Islands (McAdoo et al. 2008), Sumatra Island (Indonesia) (Paris et al. 2010), Sabusawa Island (Japan) (Goto et al. 2012) or Sanriku Coast (Japan) (Ishimura and Miyauchi 2015).

\section{Composition and geochemical properties of the sand lobes sediment}

The major mineralogical composition of sandy lobes is siliceous, with no major changes in depth. The mean mineralogical composition of the sand lobes sediment is as follows: $\mathrm{SiO}_{2} 76.31 \%, \mathrm{Al}_{2} \mathrm{O}_{3} 5.58 \%$, Fe 5.50\%, $\mathrm{MgO} 3.78, \mathrm{~K} 2.14$, $\mathrm{NaAlSi}_{3} \mathrm{O}_{8} 1.80 \%$ and $\mathrm{Ca} 1.57 \%$. The gravels have a percentage between 2.54 and $6.54 \%$, with an increasing proportion in depth with between 5.23 and $6.54 \%$ in the samples of $10-15$ and $15-20 \mathrm{~cm}$, respectively. The fraction minor than $2 \mathrm{~mm}$ sand was the dominant fraction (92.99-95.00\%). Clay and silt represented $<2 \%$ (Table 1 ).

The $\mathrm{pH}$ was alkaline, ranging between 9 and 9.5 and the electric conductivity was very low $\left(<100 \mu \mathrm{S} \mathrm{cm}^{-1}\right)$ according with the low ionic concentration observed in the extract (Table 1). Sediment reaction ( $\mathrm{pH}$ ), electric conductivity (EC) and soluble ionic concentration of the sediments (Table 1) have relatively low values with respect to seawater except for $\mathrm{pH}$, also the $\mathrm{Na}: \mathrm{Cl}$ ratio of $1.37-2.87$ is higher than seawater (0.86), however, the conductivity and the majority ions are not always good indicators due to its high solubility can wash out over time (Chagué-Goff 2010).

The organic $C$ content was extremely low $(<0.20 \%)$ and, accordingly, so was the total $N(\mathrm{TN})$ content, generally lower than the detection limit (DL) (DL $<0.01 \%$ ), however, the content in total $P(\mathrm{TP})$ is relatively high (Table 1). The high percentage of sands and low total organic carbon (TOC) supports the removal of organic matter during high-energy event consistent with a tsunamigenic origin (Chagué-Goff 2010).

The isotopic signature of the organic matter of the sand lobes sediment deposit in Bahía Inglesa is different between the upper layer BI1 and the lower levels BI2-BI4. Isotopic signature of $\delta^{13} \mathrm{C}$ shows important differences between the upper layer BI1 with a value of $25.4 \%$ and the lower layers BI2-BI4 with a range of values of -22.8 to $-21.4 \%$. The $\delta^{13} \mathrm{C}$ value of BI1 is close to the values of the coastal samples $\mathrm{CO} 1-\mathrm{CO} 3$ of -26.1 to $-27.6 \%$, while the lowest values are soil samples AT1-AT2 of -30.3 to $-31.6 \%$ (Fig. 6). Plot of the $\delta^{13} \mathrm{C}$ signature and $\mathrm{C}: \mathrm{N}$ ratio (Fig. 6) shows the grouping of samples BI2-BI4 in the range of marine origin, BI1 and $\mathrm{CO} 1-\mathrm{CO} 3$ in the range of coastal origin, and AT1-AT2 in the range of terrestrial origin (Middelburg et al. 1997; Carreira et al. 2002; Barros et al. 2010; Mackensen et al. 2019), while the upper layer BI1 have a coastal origin possibly by subsequent eolian deposition in a hyper-arid environment. The geochemical signature of the tsunami deposits is poorly conserved due to post-depositional erosion processes

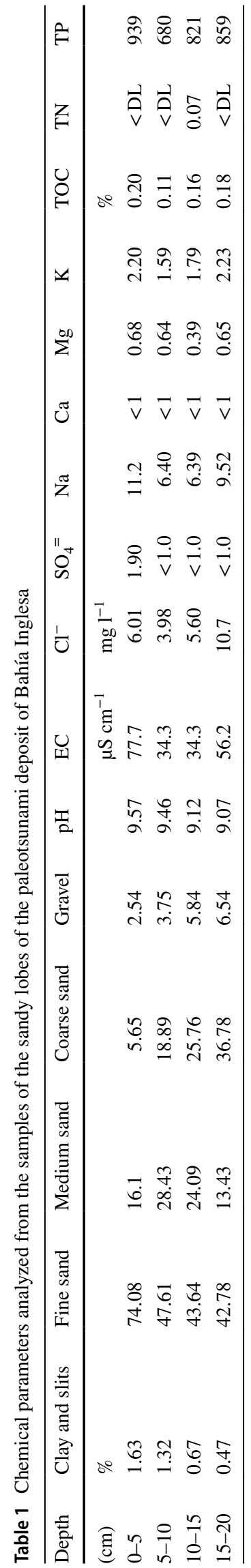



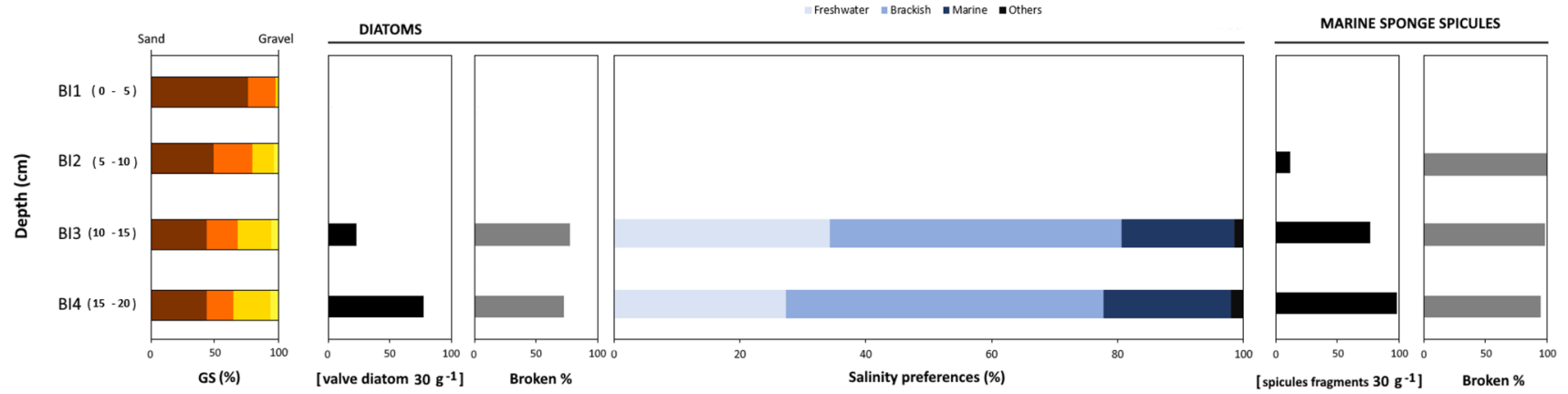

Fig. 5 Biological remains, both diatom and sponge spicules, in the sand lobes of the study area in Bahía Inglesa (Chile)

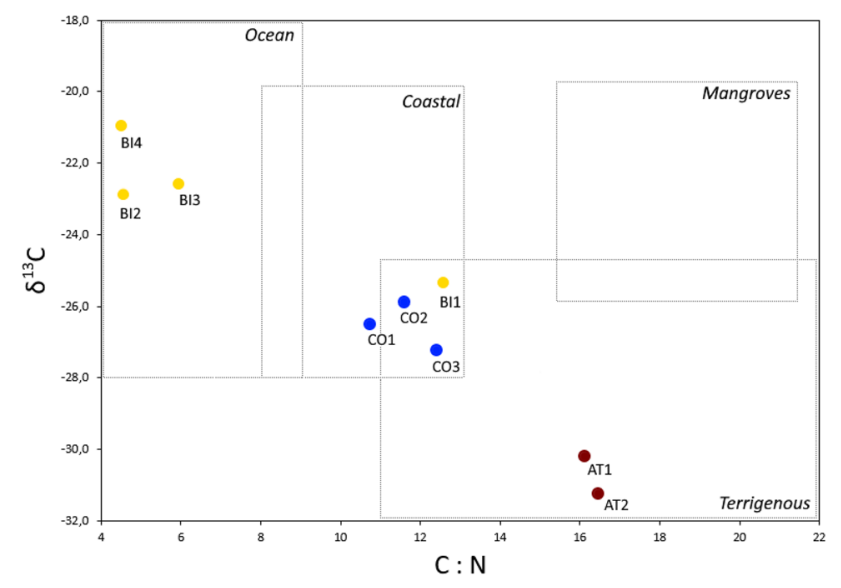

Fig. 6 Plot of the $\delta^{13} \mathrm{C}$ signature and $\mathrm{C}: \mathrm{N}$ ratio of sand lobes samples of Bahía Inglesa tsunami deposit (BI-Bahía Inglesa) and regional soils samples (CO-Copiapó; AT-Atacama). The compositional ranges illustrated in the plots are derived from previously published studies (Middelburg et al. 1997; Goñi et al. 2003; Barros et al. 2010; Yu et al. 2010; Mackenses and Schmiedl 2019)

or washing of more soluble chemical compounds (ChaguéGoff 2010), however, the disposition, genetic origin and the exceptional hyper-arid conditions of the Bahía Inglesa paleotsunami deposit on the Atacama coast have played a key role in the preservation of the original chemical signals of organic matter (Spiske et al. 2013).

\section{Biological remains, diatoms and sponge spicules}

Biological remains, diatom and sponge spicules, incorporated in sedimentary records of the sandy lobes (Fig. 7) constitute reliable stratigraphic evidence to determine the provenance of the deposit and estimate tsunami run-up beyond the landward limit of tsunami deposits (Roux et al. 1991; Dura et al. 2016; Pilarczyk et al. 2014; Hocking et al. 2017; Hong et al. 2017; Castillo-Aja et al. 2019). Also, the presence and abundance of diatoms and sponge spicules coincide with previous sedimentary and geochemical evidence in sand lobes (i.e., grain size, carbon content, trace elements, isotopes signature) (Figs. 5, 6) all of them indicative of a tsunamigenic origin. A total of 27 diatom taxa were observed in sedimentary deposits of Bahía Inglesa (Table S2). The upper levels BI1-BI2 $(0-5 \mathrm{~cm}, 5-10 \mathrm{~cm})$ showed no presence of diatoms, but the lower levels BI3-BI4 $(10-15 \mathrm{~cm}$, $15-20 \mathrm{~cm}$ ) showed small diatom concentrations, estimated between 19.5 and 82.6 diatom valves per $30 \mathrm{~g}$. Compositions of diatom communities were similar between both levels BI3-BI4: a mixture of freshwater, brackish, and marine taxa with a high percentage of brackish/marine diatoms (53.8-62.4\%). Of particular importance were planktonic marine taxa such as Paralia sulcata, Aptinoptychus senarius, and Amphitetras antediluviana (Fig. 7). Alkaline conditions lead to a poor conservation status of diatom valves, and a large proportion of valves were fragmented (70.5-78.9\%) (Fig. 7). Allochthonous diatom marine communities or a chaotic mixture of marine, brackish, and freshwater taxa in coastal or continental deposits may constitute evidence of marine tsunami events, as documented in other paleotsunami deposits in the Chilean coast and South America (e.g., Chagué-Goff et al. 2011, 2015; Goff et al. 2011) or in other regions of the world (e.g., Hemphill-Haley 1995; Sawai et al. 2002; Dura et al. 2016).

Mainly four morphotypes of marine sponge spicules were observed in sedimentary deposits of Bahía Inglesa (Fig. 7). The high fragmentation of spicules (90-100\%) prevented their identification at the species level. Type- 1 sponge spicules, the most abundant morphotype, were monactinal, monaxon, and slightly curved, showed a smooth surface, and they measured 715.6 \pm 97.15 (592.7-810.4) $\mu \mathrm{m}$ long and $10.3 \pm 2.61(8.4-12.5) \mu \mathrm{m}$ wide. Type- 2 sponge spicules were long, acanthostyle, and slightly curved, with a microspine surface. Larger spicule fragments were $134.7 \pm 48.35$ (90.3-188.7) $\mu \mathrm{m}$ long and 5.2 $\pm 0.78(4.1-6.0) \mu \mathrm{m}$ wide. Type-3 sponge spicules were long, narrow, tylostyle, and slightly curved and showed a smooth surface. Larger fragments were $215.6 \pm 37.15(187.5-244.6) \mu \mathrm{m}$ long and $4.5 \pm 1.08(3.2-5.8) \mu \mathrm{m}$ wide. Type- 4 sponge spicules were 
Fig. 7 Diatoms taxa (a-n) and marine sponge spicules (o-u) presents in Bahía Inglesa sedimentary deposits: a Aptinoptychus senarius (Ehrenberg) Ehrenberg; b Amphitetras antediluviana Ehrenberg; c Diploneis dydima (Ehrenberg) Ehrenberg; d Halamphora turgida (Gregory) Levkov; e Paralia sulcata (Ehrenberg) Cleve; $\mathbf{f}$ Cocconeis distans W. Gregory; g Achnanthidium minutissimum (Kützing) Czarnecki; h Pseudostaurosira brevistriata (Grunow) D.M.Williams and Round; i Tabellaria flocculosa (Roth) Kützing; j Opephora sp.; k Eunotia implicata Ehrenberg; $\mathbf{l}$ Pinnularia borealis Ehrenberg; m Pinnularia microstauron (Ehrenberg) Cleve; n Caloneis sp.; $\mathbf{o - q}$ type 1, fragments of monactinal monaxon spicules slightly curved with smooth surface; $\mathbf{r}-\mathbf{s}$ type 2 , fragments of monactinal monaxon spicules slightly curved with microspines; $\mathbf{t}$ type 3 , fragments of tylostyle spicules; $\mathbf{u}$ type 4 , triradiate spicules. (scale $\operatorname{bar}=10 \mu \mathrm{m}$ )

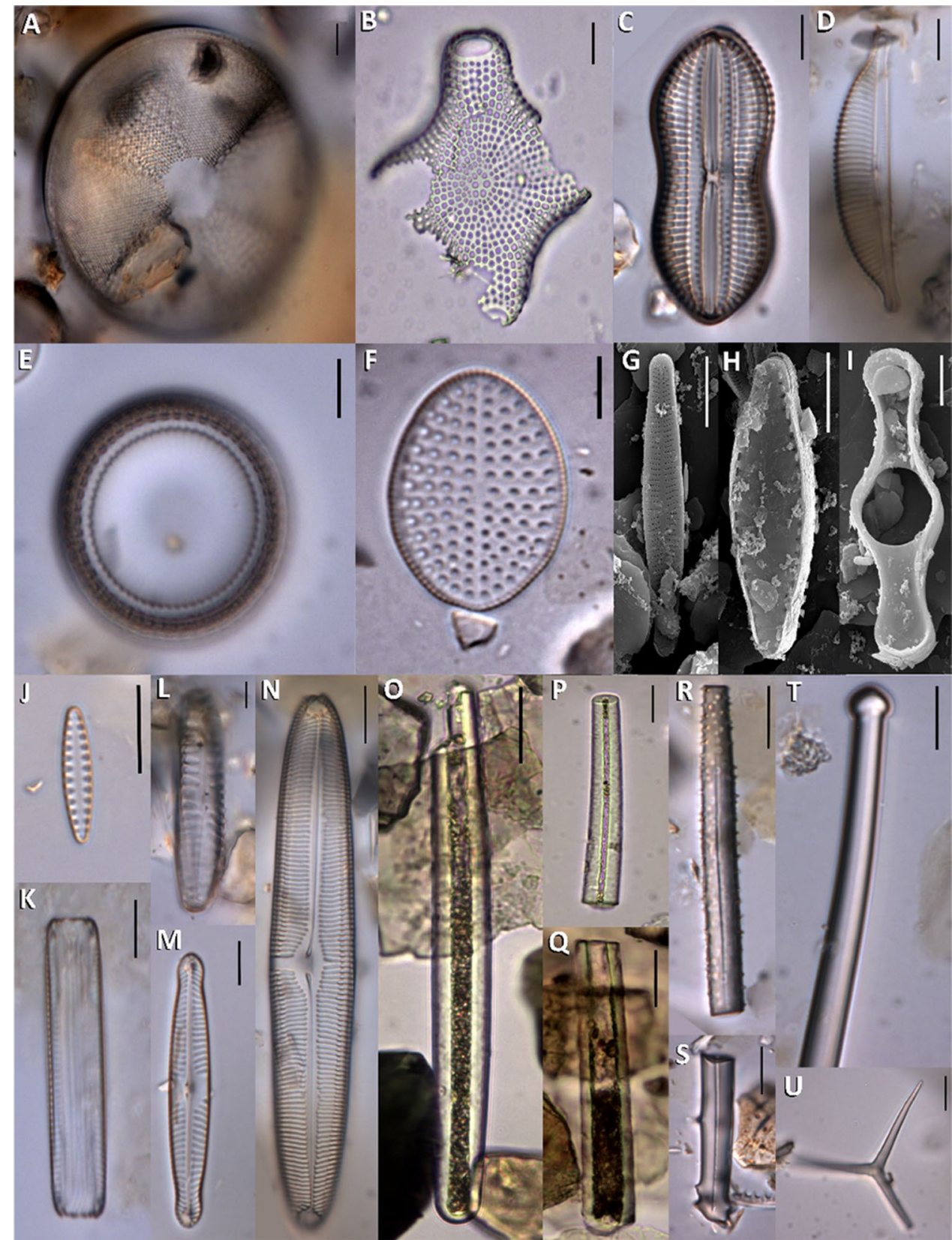

triradiate, and their average axis length was $18.77 \pm 3.8$ (15.2-26.1) $\mu \mathrm{m}$. The upper level BI1 $(0-5 \mathrm{~cm})$ showed no presence of sponge spicules. The middle level BI2 $(5-10 \mathrm{~cm})$ showed a very low concentration (10.7 fragments of spicules per $30 \mathrm{~g}$ ), while concentrations were slightly higher in the lower levels BI2-BI4 $(10-15 \mathrm{~cm}, 15-20 \mathrm{~cm})$, with 83.3 and 92.5 fragments of spicules per $30 \mathrm{~g}$, respectively (Fig. 5). Also, the high fragmentation of diatom valves and sponge spicules (Fig. 5), could constitute evidence of a highenergy turbulent event, compatible with a tsunami (Dawson et al. 1996; Sawai et al. 2002; Smith et al. 2004; Witter et al. 2009).

\section{Conclusions}

Cliff-top boulder fields are of great interest as evidence of the high-energy tsunamigenic events that repeatedly threaten the Pacific coast of South America. Therefore, the knowledge of these records plays a key role in the historical reconstruction of these catastrophic phenomena, their magnitude, and their consequences on coastal geomorphology. In this work, we studied a cliff-top boulder field associated with three sand lobes oriented towards land, which has been described and interpreted as a sedimentary deposit on a paleocliff originated by a tsunamigenic event in the geomorphological context of a hanging paleocoast. The sedimentary 
deposit in Bahia Inglesa is located on the margin of a marine terrace at a height $+30-40 \mathrm{~m}$ above another lower marine terrace that constituted the paleocoastal level at the time of the tsunamigenic event, which based on the previously known geomorphological context regarding the ages of these terraces, must have occurred between interglacial periods MIS 7 (ca. $210 \pm 10 \mathrm{ky}$ ) and MIS5e (ca.125 $\pm 5 \mathrm{ky}$ ). The morphometry of the boulders suggests that they could not be transported by rolling, and the majority of Transport figure (TF) values calculated from boulder weight $(\sim 1.15 \mathrm{t})$ indicate that the energy required for the waves to move these blocks exceeds the established threshold to consider a tsunamigenic event (TF > 1000), consistently with the arrangement of the boulders on the margin of the paleocliff, both in relation to distance from the coastline $(\sim 112.78 \mathrm{~m})$ and to orientation $\left(\sim 129^{\circ}\right)$. Moreover, the distribution of the elongated sand lobes behind the field of boulders suggests a directionality from sea to land; the composition, with a high percentage of sand (90-95\%) and low organic matter content $(<0.2 \%)$, is consistent with a high-energy event; and the lower levels in depth $(5-20 \mathrm{~cm})$ and the stable carbon isotope signature indicates a marine origin of the organic matter. In addition, the siliceous biological remains, such as diatoms and spicules from marine sponges, constitute direct evidence of the marine origin of the sediment in sand lobes. The preservation of geochemical signs and biological remains in sand lobes of this paleotsunami deposit has been favoured by the extreme climatic aridity of the coast of the Atacama Desert. Therefore, tsunamis, as catastrophic events of very high energy, originate complex sedimentary deposits with a great heterogeneity and chaotic structure, whose correct identification can be very difficult and requires a multiple approach to rule out other possible origins.

Supplementary Information The online version contains supplementary material available at https://doi.org/10.1007/s12665-022-10259-2.

Acknowledgements We thank Alejandro Gómez Pazo (Faculty of Geography, USC) for helping us with the statistical analysis.

Funding Open Access funding provided thanks to the Universidade da Coruña-CISUG, trough CRUE-CSIC agreement with Springer Nature. The Consellería de Educación, Universidade e Formación Profesional of the Xunta de Galicia funded this research through the Axudas a consolidación e estruturacion de unidades de investigación competitivas do SUG del Plan Galego IDT, Ambiosol Group (2018-PG036). Rafael Carballeira is grateful for a PhD fellowship from the Xunta de Galicia (Plan I2C).

\section{Declarations}

Conflict of interests The authors have not disclosed any competing interests.

Open Access This article is licensed under a Creative Commons Attribution 4.0 International License, which permits use, sharing, adaptation, distribution and reproduction in any medium or format, as long as you give appropriate credit to the original author(s) and the source, provide a link to the Creative Commons licence, and indicate if changes were made. The images or other third party material in this article are included in the article's Creative Commons licence, unless indicated otherwise in a credit line to the material. If material is not included in the article's Creative Commons licence and your intended use is not permitted by statutory regulation or exceeds the permitted use, you will need to obtain permission directly from the copyright holder. To view a copy of this licence, visit http://creativecommons. org/licenses/by/4.0/.

\section{References}

Abad M, Izquierdo T, Cáceres M, Bernárdez E, Rodríguez-Vidal J (2019) Coastal boulder deposit as evidence of an ocean-wide prehistoric tsunami originated on the Atacama Desert coast (northern Chile). Sedimentology 67:1505-1528. https://doi.org/10.1111/ sed. 12570

Achurra LE (2004) Cambios del nivel del mar y evolución tectónica de la cuenca neógena de Caldera, III Región. PhD dissertation, Universidad de Chile, Santiago

Aedo D, Melnick D, Garrett E, Pino M (2021) Origen y distribución de depósitos de tsunami en la marisma de Chaihuín $\left(40^{\circ} \mathrm{S} / 73,5^{\circ} \mathrm{O}\right)$, Chile. Andean Geol 48:125-152. https://doi.org/10.5027/andge ov48n1-3258

Bahlburg H, Spiske M (2012) Sedimentology of tsunami inflow and backflow deposits: key differences revealed in a modern example. Sedimentology 59:1063-1086. https://doi.org/10.1111/j.13653091.2011.01295.x

Bahlburg H, Spiske M (2015) Styles of early diagenesis and the preservation potential of onshore tsunami deposits-a re-survey of Isla Mocha, Central Chile, 2 years after the February 27, 2010, Maule tsunami. Sediment Geol 326:33-44. https://doi.org/10. 1016/j.sedgeo.2015.06.009

Barrientos S (2007) Earthquakes in Chile. In: Moreno T, Gibbons W (eds) The geology of Chile. The Geological Society of London, London, pp 263-287

Barros GV, Martinelli LA, Oliveira-Novais TM, Ometto JP, Zuppi GM (2010) Stable isotopes of bulk organic matter to trace carbon and nitrogen dynamics in an estuarine ecosystem in Babitonga Bay (Santa Catarina, Brazil). Sci Total Environ 408:2226-2232. https://doi.org/10.1016/j.scitotenv.2010.01.060

Browne A (2011) Coarse coastal deposits as palaeo-environmental archives for storms and tsunamis. PhD dissertation, Southern Cross University, Lismore

Campos R (2016) Análisis de Marejadas Históricas y recientes en las costas de Chile. Memoria de Título de Ingeniería Civil Oceánica de la Universidad de Valparaíso, Valparaíso

Carreño CA (2012) Ambiente deposicional de la Formación Bahía Inglesa (Neógeno) en la cuenca de Caldera, III Región Chile. Memoria Geología. Universidad de Chile, Santiago de Chile

Carreira R, Wagener ALR, Readman JW, Fileman TW, Macko SA, Veiga A (2002) Changes in the sedimentary organic carbon pool of a fertilized tropical estuary, Guanabara Bay, Brazil: an elemental, isotopic and molecular marker approach. Mar Chem 79:207227. https://doi.org/10.1016/S0304-4203(02)00065-8

Castillo-Aja R, Ramírez-Herrera MT, Machain-Castillo ML, Goguitchaichvili A, Cejudo R (2019) Sedimentary and microfossil imprint from historical earthquakes and tsunamis, Jalisco coast, Mexican subduction. Mar Geol 407:32-43. https://doi.org/10. 1016/j.margeo.2018.10.004 
Castro Correa CP (2014) Evaluación de riesgos ambientales en ámbitos urbanos costeros del semiárido chileno: Caldera. $\mathrm{PhD}$ dissertation, University of Zaragoza

Cereceda P, Larraín H, Oses P, Lázaro P, García JL, Hernández V (2000) El factor clima en la floración del desierto en los años “"El Niño"” 1991 y 1997. Rev De Geogr Norte Gd 27:37-52

Chagué-Goff C (2010) Chemical signatures of palaeotsunamis: a forgotten proxy? Mar Geol 271:67-71. https://doi.org/10.1016/j. margeo.2010.01.010

Chagué-Goff C, Schneider JL, Goff JR, Dominey-Howes D, Strotz L (2011) Expanding the proxy toolkit to help identify past eventslessons from the 2004 Indian Ocean Tsunami and the 2009 South Pacific Tsunami. Earth-Sci Rev 107:107-122. https://doi.org/10. 1016/j.earscirev.2011.03.007

Chagué-Goff C, Goff J, Wong HK, Cisternas M (2015) Insights from geochemistry and diatoms to characterize a tsunami's deposit and maximum inundation limit. Mar Geol 359:22-34. https://doi.org/ 10.1016/j.margeo.2014.11.009

Corey AT (1949) Influence of shape on the fall velocity of sand grains. $\mathrm{PhD}$ dissertation, M.S. Colorado Agricultural and Mechanical College

Costa PJM, Andrade C (2020) Tsunami deposits: present knowledge and future challenges. Sedimentology 67:1505-1528. https://doi. org/10.1111/sed.12724

Dahnke WC, Whitney DA (1988) Measurement of soil salinity. In: Dahnke WC (ed) Recommended chemical soil test procedures for the North Central Region. North Dakota Agricultural Experiment Station ND-499, United States (North Dakota), Fargo

Dellavalle NB (1992) Determination of soil-paste $\mathrm{pH}$ and conductivity of saturation extract. In: Dellavalle NB (ed) Handbook on reference methods for soil analysis. Soil and Plant Analysis Council, Inc., Athens

Donnelly J, Goff J, Chagué-Goff C (2017) A record of local storms and trans-Pacific tsunamis, eastern Banks Peninsula, New Zealand. The Holocene 27:496-508. https://doi.org/10.1177/09596 83616670222

Dura T, Hemphill-Haley E, Sawai Y, Horton BP (2016) The application of diatoms to reconstruct the history of subduction zone earthquakes and tsunamis. Earth-Sci Rev 152:181-197. https:// doi.org/10.1016/j.earscirev.2015.11.017

Encinas A, Finger KL, Nielsen SN, Lavenu A, Buatois LA, Peterson DE, LeRoux JP (2008) Rapid and major coastal subsidence during the late Miocene in south-central Chile. J S Am Earth Sci 25:157-175. https://doi.org/10.1016/j.jsames.2007.07.001

Frenguelli J (1929) Diatomee fossili delle conche saline del deserto chileno-boliviano. Bol Soc Geol Ital 47:185-236

Frenguelli J (1936) Diatomeas de la caliza de la Cuenca de Calama. Rev Mus La Plata, Paleontol 1:3-120

Fritz H, Petroff CM, Catalán PA, Cienfuegos R, Winckler P, Kalligeris N, Weiss R, Barrientos SE, Meneses G, Valderas-Bermejo C, Ebeling C, Papadopoulos A, Contreras M, Almar R, Domínguez JC, Synolakis CE (2011) Field survey of the 27 February 2010 Chile tsunami. Pure and Appl Geophys 168:1989-2010. https://doi.org/ 10.1007/s00024-011-0283-5

Gee GW, Bauder JW (1986) Particle size analysis. In: Klute (ed) Methods of soil analysis, Part A, 2nd edn, vol 9. American Society of Agronomy, Madison, pp 383-411

Godoy E, Marquardt C, Blanco N (2003). Carta Caldera, Región de Atacama. Servicio Nacional de Geología y Minería. Carta Geológica de Chile, Serie Geología Básica 76:38

Goff J, Lamarche G, Pelletier B, Chagué-Goff C, Strotz L (2011) Predecessors to the 2009 South Pacific tsunami in the Wallis and Futuna archipelago. Earth-Sci Rev 107:91-106. https://doi.org/10.1016/j. earscirev.2010.11.003

González G, Cembrano J, Carrizo D, Macci A, Schneider H (2003) The link between forearc tectonics and Pliocene-Quaternary deformation of the Coastal Cordillera, northern Chile. J S Am Earth Sci 16:321-342. https://doi.org/10.1016/S0895-9811(03) 00100-7

Goñi MA, Teixeira MJ, Perkeya DW (2003) Sources and distribution of organic matter in a river-dominated estuary (Winyah Bay, SC, USA). Estuar Coast Shelf Sci 57:1023-1048. https://doi.org/10. 1016/S0272-7714(03)00008-8

Goto K, Miyagi K, Kawana T, Takahashi J, Imamura F (2011) Emplacement and movement of boulders by known storm waves field evidence from the Okinawa Islands, Japan. Mar Geol 283:66-78. https://doi.org/10.1016/j.margeo.2010.09.007

Goto K, Sugawara D, Ikema S, Miyagi T (2012) Sedimentary processes associated with sand and boulder deposits formed by the 2011 Tohoku-oki tsunami at Sabusawa Island, Japan. Sediment Geol 282:188-198. https://doi.org/10.1016/j.sedgeo.2012.03.017

Goy JL, Macharé J, Ortlieb L, Zazo C (1992) Quaternary shorelines and neotectonics in southern Peru: the Chala embayment. Quat Int 15-16:99-112

Guzmán N, Marquardt C, Ortlieb L, Frassinetti D (2003) La malacofauna neógena y cuaternaria del área de Caldera $\left(27^{\circ}-28^{\circ} \mathrm{S}\right)$ : especies y rangos bioestratigráficos. IX Congreso Geológico Chileno $1: 476-481$

Hartley AJ, May G, Chong G, Turner P, Kape SJ, Jolley EJ (2000) Development of a continental forearc: a Cenozoic example from the Central Andes, northern Chile. Geology 28:331-334. https:// doi.org/10.1130/0091-7613(2000)28\%3c331:DOACFA\%3e2.0. $\mathrm{CO} ; 2$

Hemphill-Haley E (1993) Taxonomy of recent and fossil (Holocene) diatoms (Bacillariophyta) from northern Willapa Bay, Washington. US Geol Surv 93-289:1-151. https://doi.org/10.3133/ofr93 289

Hemphill-Haley E (1995) Diatom evidence for earthquake-induced subsidence and tsunami 300 years ago in southern coastal Washington. Geol Soc Am Bull 107:367-378. https://doi.org/10.1130/ 0016-7606(1995)107\%3c0367:DEFEIS\%3e2.3.CO;2

Hocking EP, Garrett ED, Cisternas M (2017) Modern diatom assemblages from Chilean tidal marshes and their application for quantifying deformation during past great earthquakes. J Quat Sci 32:396-415. https://doi.org/10.1002/jqs.2933

Hofmann G, Werum M, Lange-Bertalot H (2011) Diatomeen im Süsswasser-Benthos von Mitteleuropa: Bestimmungsflora Kieselalgen für die ökologische Praxis über 700 der häufigsten Artenund ihre Ökologie. A.R.G Gantner Verlag, Ruggell

Hong I, Dura T, Ely LL, Horton BP, Nelson AR, Cisternas M, Nikitina D, Wesson RL (2017) A 600-year-long stratigraphic record of tsunamis in south-central Chile. The Holocene 27:39-51. https:// doi.org/10.1177/0959683616646191

Hustedt F (1927) Fossile Bacillariaceen aus dem Loa-Becken in der Atacama-Wüste. Chile Arch Hydrobiol 18:224-251

Imamura F, Goto K, Ohkubo S (2008) A numerical model for the transport of a boulder by tsunami. J Geophys Res 113-7:1-12. https:// doi.org/10.1029/2007JC004170

Ishimura D, Miyauchi T (2015) Historical and paleo-tsunami deposits during the last 4000 years and their correlations with historical tsunami events in Koyadori on the Sanriku Coast, northeastern Japan. Prog Earth Planet Sci 2:16. https://doi.org/10.1186/ s40645-015-0047-4

Klein E, Vigny C, Fleitout L, Grandin R, Jolivet R, Rivera E, Métois M (2017) A comprehensive analysis of the Illapel $2015 \mathrm{Mw}$ 8.3 earthquake from GPS and InSAR data. Earth Planet Sci Let 469:123-134. https://doi.org/10.1016/j.eps1.2017.04.010

Krammer K, Lange-Bertalot H (2000) Bacillariophyceae. In: Ettl H, Gerloff J, Heynig H, Mollenhauer D (eds) Süsswasser flora von Mitteleuropa, Band 2/1-4. Gustav Fischer Verlag, Stuttgart

Laursen J, Scholl DW, von Huene R (2002) Neotectonic deformation of the central Chile margin: deepwater forearc basin formation in 
response to hot spot ridge and seamount subduction. Tectonics 21:2-27. https://doi.org/10.1029/2001TC901023

León T, Vargas G, Salazar D, Goff J, Guendon JL, Andrade P, Álvarez G (2019) Geo-archaeological records of large holocene tsunamis along the hyperarid coastal Atacama Desert in the major northern Chile seismic gap. Quat Sci Rev 220:335-338. https://doi.org/10. 1016/j.quascirev.2019.07.038

Leonard EM, Muhs DR, Ludwig KR, Wehmiller JF (1994) Coral uranium-series ages and mollusc amino-acid ratios from uplifted marine terrace deposits. Morro de Copiapo, northcentral Chile, American Quaternary Association Program and Abstracts (AMQUA), 13th Biennal Meeting, pp 223

Macharé J, Ortlieb L (1992) Plio-quaternary vertical motions and the subduction of the Nazca Ridge, central coast of Peru. Tectonophysics 205:97-108. https://doi.org/10.1016/0040-1951(92) 90420-B

Mackensen A, Schmiedl G (2019) Stable carbon isotopes in paleoceanography: atmosphere, oceans, and sediments. Earth-Sci Rev 197:102893. https://doi.org/10.1016/j.earscirev.2019.102893

Marchant M, Marquardt C, Blanco N, Godoy E (2000) Foraminíferos del área de Caldera $\left(26^{\circ} 45^{\prime}-28^{\circ} \mathrm{S}\right)$ y su utilización como indicadores cronoestratigráficos del Neógeno. IX Congreso Geológico Chileno 1:476-481

Marquardt C, Blanco N, Godoy E, Lavenu A, Ortlieb L, Marchant M, Guzmán N (2000a) Estratigrafía del Cenozoico superior en el área de Caldera $\left(26^{\circ} 45^{\prime}-28^{\circ} \mathrm{S}\right)$, III Región de Atacama, Chile. Actas IX Congreso Geológico Chileno 1:504-508

Marquardt C, Lavenu A, Ortlieb L (2000b) Tectónica compresiva neógena en el dominio costero del área de Caldera y Mejillones Norte De Chile. IX Congreso Geológico Chileno 2:583-587

Marquardt C, Lavenu A, Ortlieb L, Godoy E, Comte D (2004) Coastal neotectonics in Southern Central Andes: uplift and deformation of marine terraces in Northern Chile $\left(27^{\circ} \mathrm{S}\right)$. Tectonophysics 394:193-219. https://doi.org/10.1016/j.tecto.2004.07.059

McAdoo BG, Moore A, Baumwoll J (2008) Indigenous knowledge and the near field population response during the 2007 Solomon Islands tsunami. Nat Hazards 48:73-82. https://doi.org/10.1007/ s11069-008-9249-z

Middelburg JJ, Nieuwenhuize J, Lubberts RK, van de Plasschke O (1997) Organic carbon isotope systematic of coastal marshes. Estuar Coast Shelf Sci 45:681-687. https://doi.org/10.1006/ ecss.1997.0247

Monárdez P, Acuña H, Scott D (2008) Evaluation of the potential of wave energy in Chile. In: Proceedings of the ASME 27th international conference on offshore mechanics and arctic engineering, OMAE2008. Estoril, Portugal.

Nott J (2003) Tsunami or storm waves? Determining the origin of a spectacular field of wave emplaced boulders using numerical storm surge and wave models and hydrodynamic transport equations. J Coast Res 19:348-356

Ortlieb L, Guzmán N, Marquardt C, Vargas G (1997) El Cuaternario marino del Norte de Chile: Revisiones cronológicas e identificación posible de depósitos de $400 \mathrm{Ka}$. Actas VIII Congreso Geológico Chileno 1:371-375

Paris R, Fournier J, Poizot E, Etienne S, Morin J, Lavigne F, Wassmer P (2010) Boulder and fine sediment transport and deposition by the 2004 tsunami in Lhok Nga (western Banda Aceh, Sumatra, Indonesia): a coupled offshore-onshore model. Mar Geol 268:43-54. https://doi.org/10.1016/j.margeo.2009.10.011

Paskoff R (1970) Recherches géomorphologiques dans le Chili semi aride. Biscaye Frères, Bordeaux

Pilarczyk JE, Dura T, Horton BP, Engelhart SE, Kemp AC, Sawai Y (2014) Microfossils from coastal environments as indicators of paleo-earthquakes, tsunamis and storms. Palaeogeogr Palaeoclimatol Palaeoecol 413:144-157. https://doi.org/10.1016/j. palaeo.2014.06.033
Quezada J, Gonzalez G, Dunai T, Jensen A, Juez-Larre J (2007) Alzamiento litoral Pleistoceno del norte de Chile: edades Ne-21 de la terraza costera más alta del área de Caldera-Bahía Inglesa. Rev Geol Chile 34:81-96. https://doi.org/10.4067/S0716-02082 007000100005

Radtke U (1987) Palaeo sea levels and discrimination of the last and the penultimote interglacial fossiliferous deposits by absolute dating methods and geomorphological investigations illustrated from marine terraces in Chile. Berl Geogr Stu 25:313-342

Renberg I (1990) A procedure for preparing large sets of diatom slides from sediment cores. J Paleolimnol 4:87-90. https://doi. org/10.1007/BF00208301

Robinson E, Khan S, Rowe DA, Coton R (2008) Size of boulders moved and emplaced by recent hurricanes, Jamaica. In: Mastronuzzi G, Pignatelli P, Sansó P, Milella M, Selleri G (eds) Abstract volume of the 2nd International Tsunami Field Symposium, Ostuni (Italy) and Ionian Islands (Greece), 22-28 September 2008, vol 6. GIS Coast Research Publication, pp 135-138

Roig-Munar FX (2016) Blocs de tempesta i tsunami a les costes rocoses de les Illes Balears. Anàlisi geomorfològica i morfomètrica. PhD dissertation, University of Barcelona

Roig-Munar FX, Vilaplana JM, Rodríguez-Perea A, Martín-Prieto JA, Gelabert B (2017) Presencia de bloques de tsunami en los acantilados de Punta Gavina (Formentera, Illes Balears). GeoTemas 17:223-226. (ISSN 2255-1379)

Roux M, Servant-Vildary S, Servant M (1991) Inferred ionic composition and salinity of a Bolivia Quaternary lake, as estimated from fossil diatoms in the sediments. Hydrobiologia 210:3-18. https://doi.org/10.1007/BF00014319

Ruiz S, Madariaga R (2018) Historical and recent large megathrust earthquakes in Chile. Tectonophysics 733:37-56. https://doi. org/10.1016/j.tecto.2018.01.015

Rumrich U, Lange-Bertalot H, Rumrich M (2000) Diatomeen der Anden von Venezuela bis Patagonien/Feuerland und zwei weitere Beiträge. Diatoms of the Andes. From Venezuela to Patagonia/Tierra del Fuego and two additional contributions. Iconographia Diatomologica 9:1-673

Sawai Y, Nasu H, Yasuda Y (2002) Fluctuations in relative sea-level during the past 3000 year in the Onnetoh estuary, Hokkaido, northern Japan. J Quat Sci 17:607-622. https://doi.org/10.1002/ jqs.708

Scheffers AM, Kinis S (2014) Stable imbrication and delicate/unstable settings in coastal boulder deposits: indicators for tsunami dislocation? Quat Int 332:73-84. https://doi.org/10.1016/j. quaint.2014.03.004

Servant-Vildary S (1978) Les diatomées des dépôts lacustres quaternaires de l'Altiplano bolivien. Cahiers ORSTOM, Série Géologie 10:25-35

Servant-Vildary S, Blanco M (1984) Les diatomées fluvio-lacustres plio-pleistocènes de la Formation Charaña (Cordillère occidentale des Andes de Bolivia). Cahiers ORSTOM, Serie Géologie 14:55-102

Servant-Vildary S, Risacher F, Roux M (2002) Diatom based transfer function for estimating the chemical composition of fossil water. Calibration based on salt lakes of the Lipez area in the southwestern Bolivian Altiplano. Carnets de Géologie/Notebooks on Geology, Maintenon, Memoir 2002/01 (CG2002_M01_SSV-FR-MR).

Smith DE, Shi S, Cullingford RA, Dawson AG, Dawson S, Firth CR, Foster IDL, Fretwell PT, Haggart BA, Holloway LK, Long D (2004) The holocene storegga slide tsunami in the United Kingdom. Quat Sci Rev 23:2291-2321. https://doi.org/10.1016/j. quascirev.2004.04.001

Spiske M, Bahlburg H (2011) A quasi-experimental setting of boulder transport by the 2010 Chile tsunami (Bucalemu, Central 
Chile). Mar Geol 289:72-85. https://doi.org/10.1016/j.margeo. 2011.09.007

Spiske M, Piepenbreier J, Benavente C, Bahlburg H (2013) Preservation potential of tsunami deposits on arid siliciclastic coasts. Earth-Sci Rev 126:58. https://doi.org/10.1016/j.earscirev.2013. 07.009

Van Dam H, Mertens A, Sinkeldam J (1994) A coded checklist and ecological indicator values of freshwater diatoms from the Netherlands. Neth J Aquat Ecol 28:117-133. https://doi.org/ 10.1007/BF02334251

Verardo DJ, Froelich PN, McIntyre A (1990) Determination of organic carbon and nitrogen in marine sediments using the Carlo Erba NA-1500 analyzer. Deep-Sea Res 37:157-165

Vos PC, de Wolf H (1988) Methodological aspects of paleo-ecological diatom research in coastal areas of the Netherlands. Geol Mijnbouw 67:31-40

Vos PC, de Wolf H (1993) Diatoms as a tool for reconstructing sedimentary environments in coastal wetlands; methodological aspects. Hydrobiologia 269(270):285-296. https://doi.org/10. 1007/BF00028027

Weiss R (2012) The mystery of boulders moved by tsunamis and storms. Mar Geol 295-298:28-33. https://doi.org/10.1016/j. margeo.2011.12.001
Witkowski A, Lange-Bertalot H, Metzeltin D (2000) Diatom flora of marine coasts. I.A.R.G. Gantner Verlag, Ruggell

Witter RC, Hemphill-Haley E, Hart R, Gay L (2009) Tracking prehistoric Cascadia tsunami deposits at Nestucca Bay, Oregon. US Geological Survey, National Earthquake Hazards Reduction Program Final Technical Report 08HQGR0076 92

Yu F, Zong Y, Lloyd JN, Huang G, Leng MJ, Kendrick C, Lamb AL, Yim WW (2010) Bulk organic $\delta^{13} \mathrm{C}$ and $\mathrm{C} / \mathrm{N}$ as indicators for sediment sources in the Pearl River delta and estuary, southern China. Estuar Coast Shelf Sci 87:618-630

XLSTAT (2020) Data analysis and statistical solution for microsoft excel. Addison, Paris

Publisher's Note Springer Nature remains neutral with regard to jurisdictional claims in published maps and institutional affiliations. 